\title{
Fish for the city: meta-analysis of archaeological cod remains and the growth of London's northern trade
}

\author{
David C. Orton ${ }^{1}$, James Morris ${ }^{2,3}$, Alison Locker ${ }^{4} \&$ James H. Barrett ${ }^{5}$
}

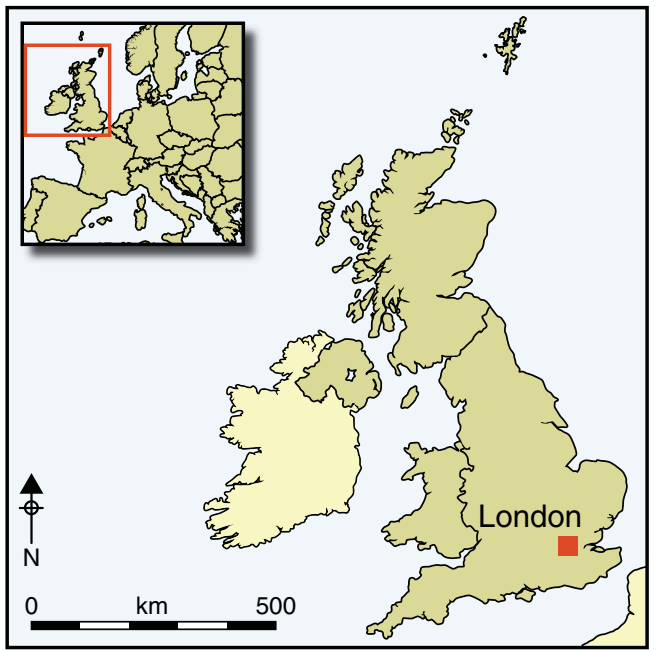

The growth of medieval cities in Northern Europe placed new demands on food supply, and led to the import of fish from increasingly distant fishing grounds. Quantitative analysis of cod remains from London provides revealing insight into the changing patterns of supply that can be related to known historical events and circumstances. In particular it identifies a marked increase in imported cod from the thirteenth century $A D$. That trend continued into the fifteenth and sixteenth centuries, after a short downturn, perhaps attributable to the impact of the Black Death, in the mid fourteenth century. The detailed pattern of fluctuating abundance illustrates the potential of archaeological information that is now available from the high-quality urban excavations conducted in London and similar centres during recent decades.

Keywords: London, marine fisheries, cod, zooarchaeology, meta-analysis, Fish Event Horizon, stable isotopes, medieval trade

Supplementary material is published online at http://antiquity.ac.uk/projgall/orton339/

\section{Introduction}

Marine fisheries for species such as cod have long played a crucial role in the economy of northern Europe (Holm et al. 1996; Starkey et al. 2009), supplying the growing cities of the North Sea and Baltic Sea basins and influencing political events from the rise

1 Institute of Archaeology, University College London, 31-34 Gordon Square, London WC1H OPY, UK (Email: d.orton@ucl.ac.uk)

2 School of Forensic and Investigative Sciences, University of Central Lancashire, J.B. Firth Building, Preston, Lancashire PR12HE,UK (Email: jmorris9@uclan.ac.uk)

3 Museum of London Archaeology, Mortimer Wheeler House, 46 Eagle Wharf Road, London N1 7ED, UK

Escaldes-Engordany, Andorra (Email: galocker@andorra.ad)

5 McDonald Institute for Archaeological Research, University of Cambridge, Downing Street, Cambridge CB2 3ER,UK (Email:jhb41@cam.ac.uk) 
of the German Hansa in the thirteenth century AD (Nedkvitne 1994; Dollinger 1999) to the composition of the present-day European Union. Their contribution to Europe's economic and environmental history remains patchily understood, however, particularly in the centuries before the introduction of systematic customs records, the earliest of which (from England) begin in 1303 (Lloyd 1991: 23-24). Drawing on accumulated zooarchaeological data from decades of high-quality commercial and rescue excavation, combined with stable isotope analysis of cod bones (Barrett et al. 2011), we adopt a simple yet effective anatomical approach to tracing the role of traded marine resources in the development of one major European city: London. This study reveals a remarkable earlythirteenth-century surge in imports of cod, following a previously documented revolution in local sea fishing around AD 1000 (Barrett et al. 2004, 2011). It also highlights subsequent vacillations in the exploitation of this species that improve our understanding of North Sea and North Atlantic trade.

\section{Background}

Zooarchaeological finds demonstrate the existence of significant marine fisheries in the North Sea for at least a millennium. A previous paper in Antiquity (Barrett et al. 2004) demonstrated a revolution in sea-fish consumption in England from approximately AD 1000, particularly associated with emerging medieval towns: cod and related marine species become much more common in sieved urban assemblages after this point, at the expense of freshwater species. Precursors are seen in the occurrence of herring at some proto-urban trading centres from the seventh to eighth centuries onwards, but again their relative contribution increased dramatically in the eleventh century. Similar trends are seen across the North Sea in Flanders (Ervynck et al. 2004).

The extent to which this 'Fish Event Horizon' was driven by demand from growing urban populations is not immediately clear. Although both urbanisation and population growth were certainly major features of the English medieval period, their rate and timing are notoriously difficult to quantify, whether from archaeological evidence or from the available historical sources (Dyer 2002; Langdon \& Masschaele 2006; Astill 2009). Changes in Christian fasting practices - potentially prohibiting consumption of terrestrial meat for as much as half the year-may also have increased demand, but again their early extent and application is poorly understood (see Barrett et al. 2004). Meanwhile, long-distance trade of stockfish (air-dried cod) from the Lofoten Islands in northern Norway to the southern North Sea littoral raises the possibility of a supply-driven explanation. Factors including warming climate, increases in ship capacities and the Viking Age diaspora might have combined to stimulate the development of this trade (Barrett et al. 2004).

Recent stable isotopic study of cod bones from various English and Flemish settlements lends support to a demand-driven explanation of the Fish Event Horizon (Barrett et al. 2011). Most sampled cod bones from the eleventh to twelfth centuries have $\delta^{13} \mathrm{C}$ and $\delta^{15} \mathrm{~N}$ values fitting a southern North Sea isotopic signature, implying that the Fish Event Horizon initially involved fishing in relatively local waters. Demand from urban populationsparticularly London-may eventually have outstripped local supply, however: from the thirteenth to fourteenth centuries, bones matching Arctic Norwegian, Icelandic or northern

(c) Antiquity Publications Ltd. 
Scottish signatures become more common. By the fifteenth to sixteenth centuries most sampled bones from London appear to have come from waters beyond the southern North Sea.

Such biomolecular approaches are extremely useful in providing positive evidence not only for imported food remains but also for the potential source of those imports. Their cost and destructive nature, however, place limits on sample sizes and hence on both the representativeness of results and the potential resolution that can be achieved. Thus, stable isotope provenancing can only provide a partial indication of broad-scale trends over time.

Late- and post-medieval expansion of England's fish supply is also historically documented, with English boats fishing around and trading with Iceland in the fifteenth century (Gardiner \& Mehler 2007) and harvesting Newfoundland waters by 1502 , following John Cabot's transatlantic expedition from Bristol in 1497 (McGhee 2003; Candow 2009). Again, however, it remains difficult to assess the relative importance of these distant fisheries in provisioning English cities over time-vis-à-vis the North Sea and other more local sources.

\section{Aims and approach}

This process of expansion to distant waters is of profound economic, social and ecological importance as an example of early food globalisation (Hoffmann 2001; Barrett 2012) but is difficult to trace using conventional historical or archaeological methods. Intermittent disruptions to imports are potentially of equal significance (e.g. Adams \& Flatman 2013: 138-40). There is thus a need for new archaeological approaches to address questions such as:

Was there a shift towards imports between the eleventh/twelfth and thirteenth/fourteenth centuries and how sudden was it?

Can any impact of the 'Black Death' of $1348-50$ be detected on the demand for food imports, either as a decrease consistent with a drop in population or an increase driven by subsequent rises in standard of living?

Did the supply of preserved cod to London increase significantly after the European discovery of the Newfoundland fishery?

The zooarchaeological approach employed here takes advantage of the fact that—prior to refrigeration - cod were typically decapitated as part of the drying process (with or without the addition of salt) for long-distance transport (e.g. Barrett 1997; Stevens \& Cumbaa 2007: 196-98; Perdikaris \& McGovern 2008: 204-207). Cranial bones found on archaeological sites are thus likely to have been from fish caught locally, while postcranial bones may represent local or imported fish. The relative abundance of cranial and postcranial bones recovered from consumer settlements is thus a guide to the likely contribution of fresh versus processed fish. Given a sufficiently continuous archaeological record—as is the case for London-fluctuating frequencies of cranial and postcranial bones can provide an indication of changes over time in the scale of local and long-range fish supplies. Moreover, by combining data at the level of individual archaeological contexts ('layers'), rather than lumped phases or periods, an unprecedented degree of temporal resolution becomes possible.

(C) Antiquity Publications Ltd. 
This simple approach is designed to complement the characterisation of cod bones using stable isotopes, providing evidence for the relative scale of imports through time where the latter contributes information on source. The present analysis is restricted to cod, since it is (a) known to have been one of the most economically important North Atlantic species over the last millennium, and (b) subject to relatively good archaeological preservation and recovery due to its size and robust morphology. In future we hope to expand consideration to other major species.

\section{Materials and methods}

\section{Zooarchaeological meta-analysis}

Published and unpublished data on the frequency and anatomical representation of cod bones were collected from 95 Roman, medieval, and post-medieval sites in London (Figure 1). While some of these would not have been considered part of London at the time of deposition, all fell within its wider economic catchment. Data including site code, stratigraphic unit (context), environmental sample number (where applicable), anatomical element and context-level dating were assembled from a combination of published reports, grey literature and raw data supplied by several institutions and individuals (see online supplementary material) — notably the archives of Museum of London Archaeology (MOLA) and those of co-author Alison Locker. Although not exhaustive, this dataset represents a very substantial portion of all well-dated cod bones recovered and identified from sites in London.

Whereas previous studies take the site or site phase as the basic unit of analysis, we achieve maximum possible temporal resolution by analysing the data at the scale of the individual context. Date ranges as given in the documentation for each context were converted into calendar years on a conservative basis, interpreting 'early $n$th century' as the first half of that century, 'mid $n$th century' as the years $25-75$, and 'late $n$th century' as the second half. Thus, 'early thirteenth to fourteenth C' becomes AD 1200-1400, 'mid tenth to early eleventh C' becomes AD 925-1050, and 'late sixteenth to mid eighteenth C' becomes AD 1550-1775. Periods such as 'Hadrianic/Trajanic', 'mid-Saxon' or 'Tudor' were converted using conventional date ranges, while AD 1950 was used as a cut-off for contexts with no end date given. Contexts with date ranges over 300 years were excluded.

For the purposes of interpreting the abundance (by number of identified specimens) of cranial and postcranial bones, 'cranial' specimens include the bones of the neurocranium, jaw apparatus, hyoid arch and gill covers, while 'postcranial' specimens include vertebrae and cleithra (an appendicular element that supports the pectoral fin just behind the head) (Figure 2). Posttemporals and supracleithra are excluded since they are anatomically located at the point where cod are decapitated and might thus end up in either processing waste or the traded product. Cleithra were clearly left in many dried cod products manufactured across the North Atlantic region during both the medieval and post-medieval periods, but fish could also be decapitated posterior to this element (cf. Barrett 1997; Stevens \& Cumbaa 2007: 196-98; Hufthammer forthcoming). Thus in some instances imported fish might be indicated solely by an overrepresentation of vertebrae. 


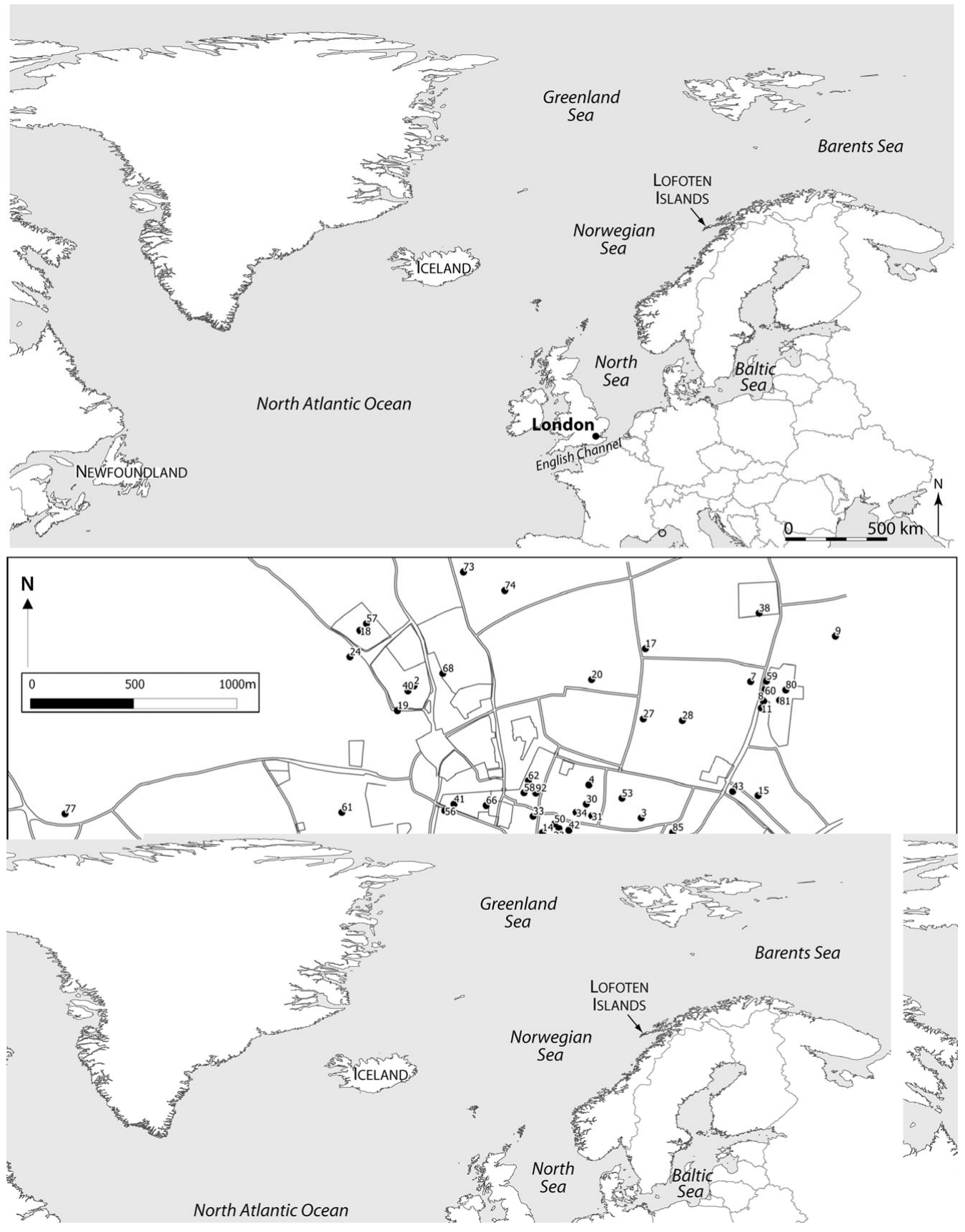

Figure 1. Location of London in its northern context (top) and 91 sites included in this study (bottom). See online supplementary information for key to site numbers. Sites 22, 23, 39 and 52 are outside the area of London shown.

(C) Antiquity Publications Ltd. 


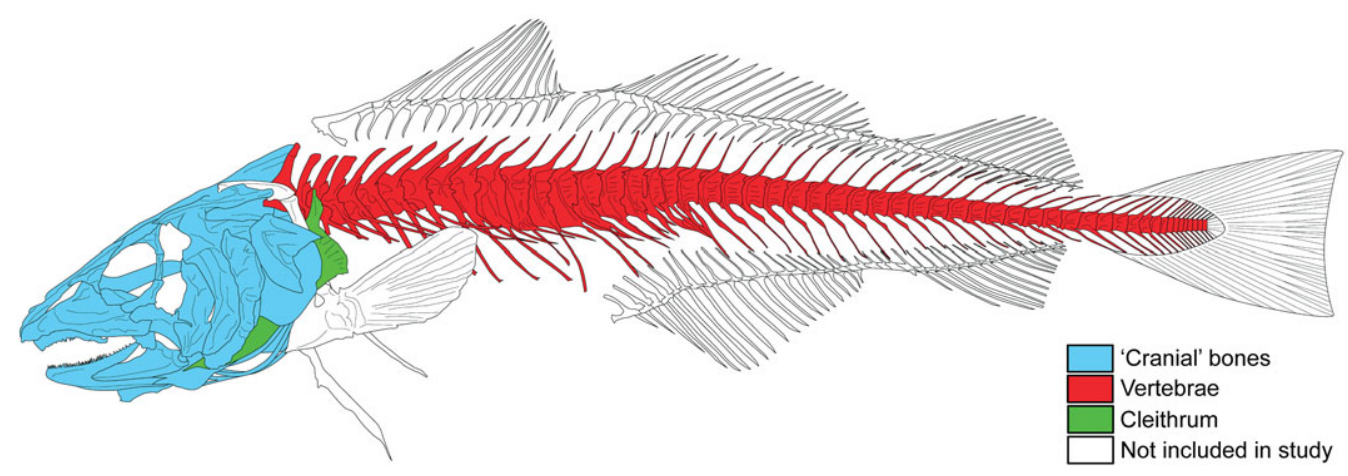

Figure 2. Cod skeleton indicating anatomical categories used here (base image (c)ArchéoZoo.org).

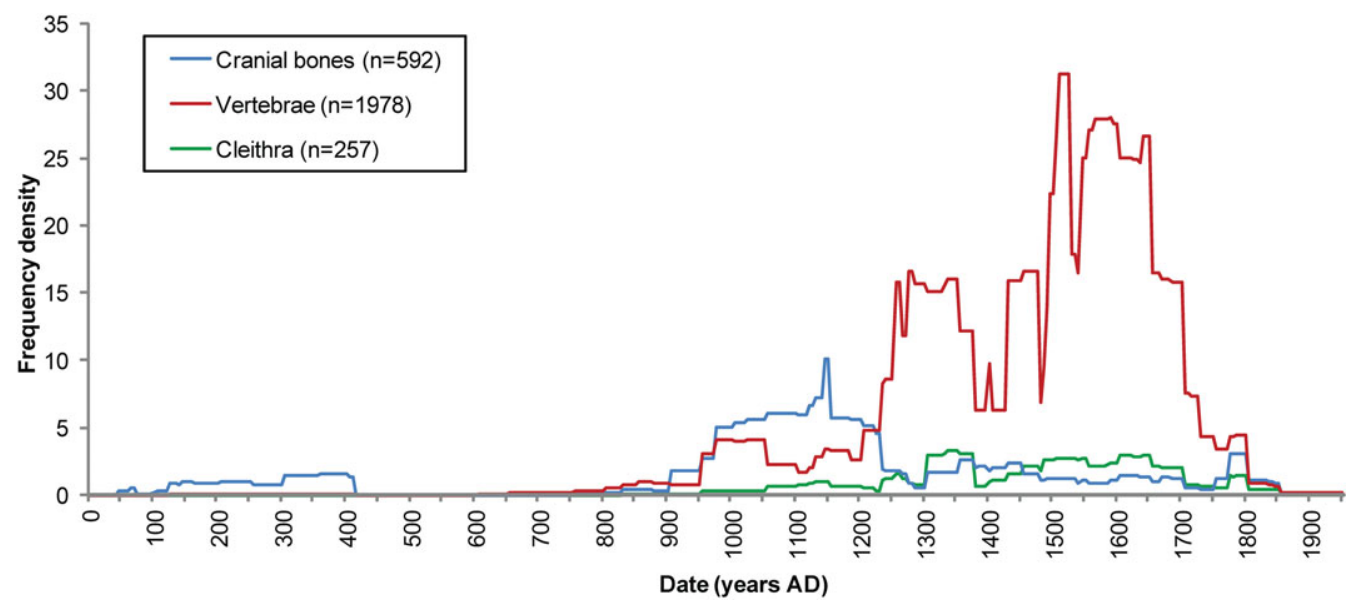

Figure 3. Estimated frequency distributions for London cod specimens dated AD 5-1950, split by anatomical group.

The data are presented using estimated frequency distributions (Figures 3 to 7). These were produced to incorporate specific dating information for each relevant archaeological context without lumping the data into coarse-grained and arbitrary chronological groups (e.g. the two-century blocks of Barrett et al. 2004). The number of relevant specimens in each context was divided by the length of its date range to give an estimate of frequency density across that range. These estimates were then summed across all contexts at five-year intervals from AD 5-1950 to produce an overall distribution. The date ranges for each specimen are shown in Figure 8, allowing assessment of chronological resolution at any point in the time series.

Apart from reflecting initial processing methods, the anatomical composition of archaeological fish bone assemblages is influenced by post-depositional preservation conditions, recovery methods and laboratory recording practices (e.g. Nicholson 1998; Barrett et al. 1999: 378-79; Nagaoka 2005). These potential sources of bias must be considered when interpreting our results. Unfortunately it is not practicable to control for preservation across the assemblages studied, but it is unlikely to vary systematically by date across so many different sites. Possible biases based on variability in field recovery

(C) Antiquity Publications Ltd. 


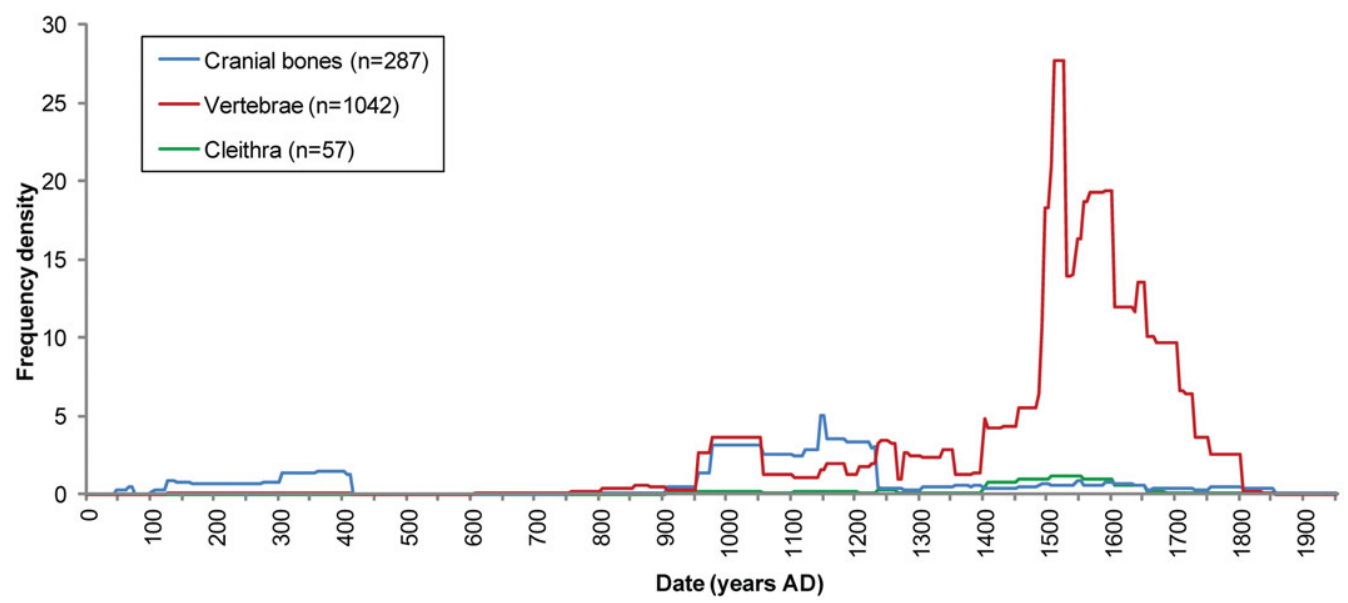

Figure 4. Estimated frequency distributions by anatomical group for London cod specimens recovered by environmental sampling/sieving.

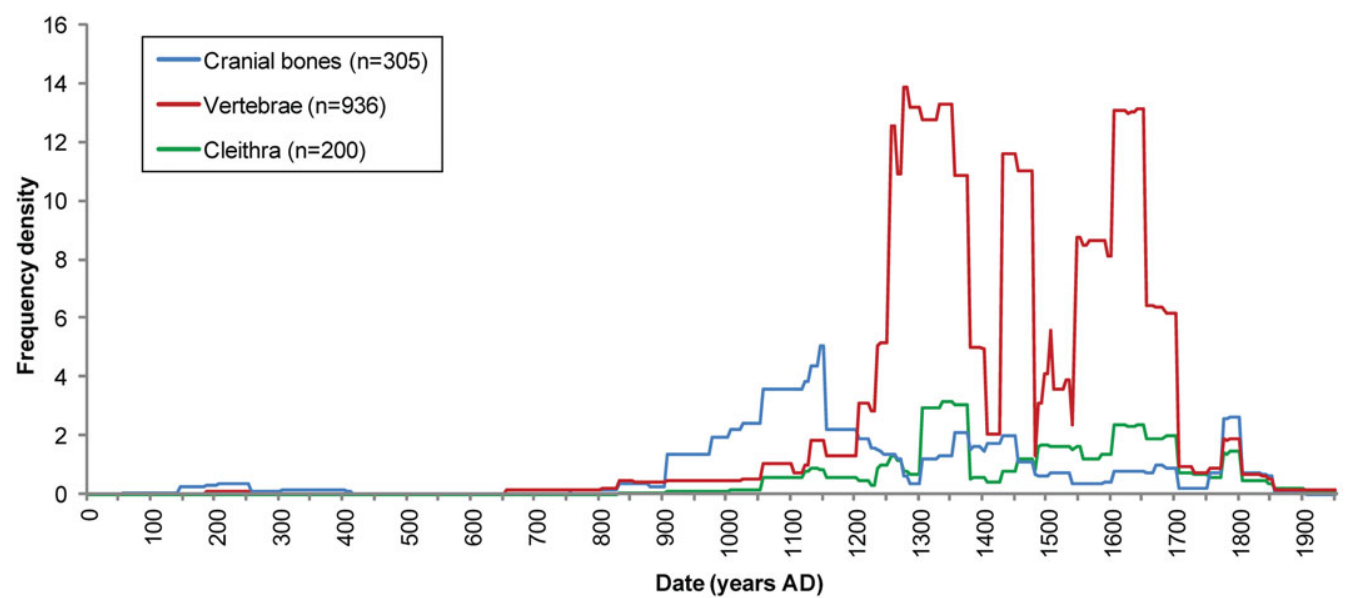

Figure 5. Estimated frequency distributions by anatomical group for hand-collected London cod specimens.

and laboratory identification practices merit further consideration and are discussed in the context of the results below.

In addition, various factors influence the absolute frequency of cod bones at any given point in the time series. Those that reflect historical processes-such as expansion in the area and population of the city - are of course objects of study rather than biases, although developments in waste disposal may have affected the chance of post-medieval fish bones ending up in well-dated urban contexts. Since the bulk of the data used here result from commercial or rescue excavations in a heavily developed urban area, preservation of features is the main determinant of archaeological 'effort', with research bias limited. Nonetheless, systematic date-correlated biases may occur in the extent of environmental sampling and post-excavation analysis. Changes in overall frequency should thus be treated with caution, although the sheer concentration of research in London means that they are likely to (C) Antiquity Publications Ltd. 


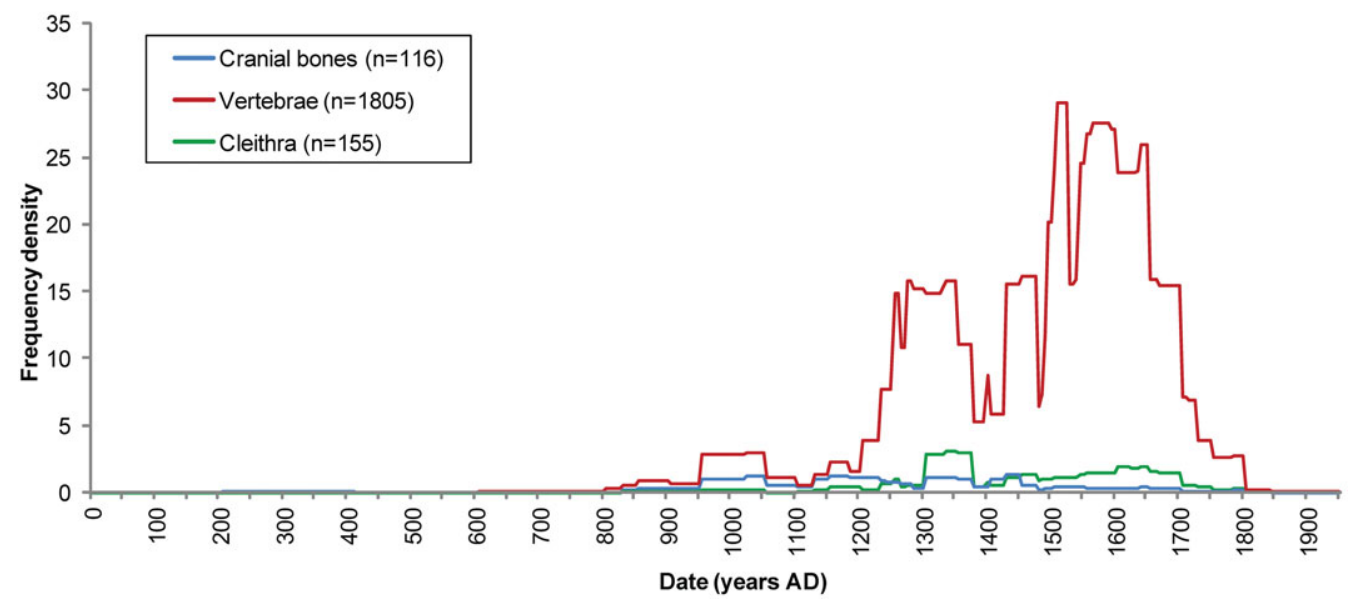

Figure 6. Estimated frequency distributions by anatomical group for London cod specimens recorded by Alison Locker.

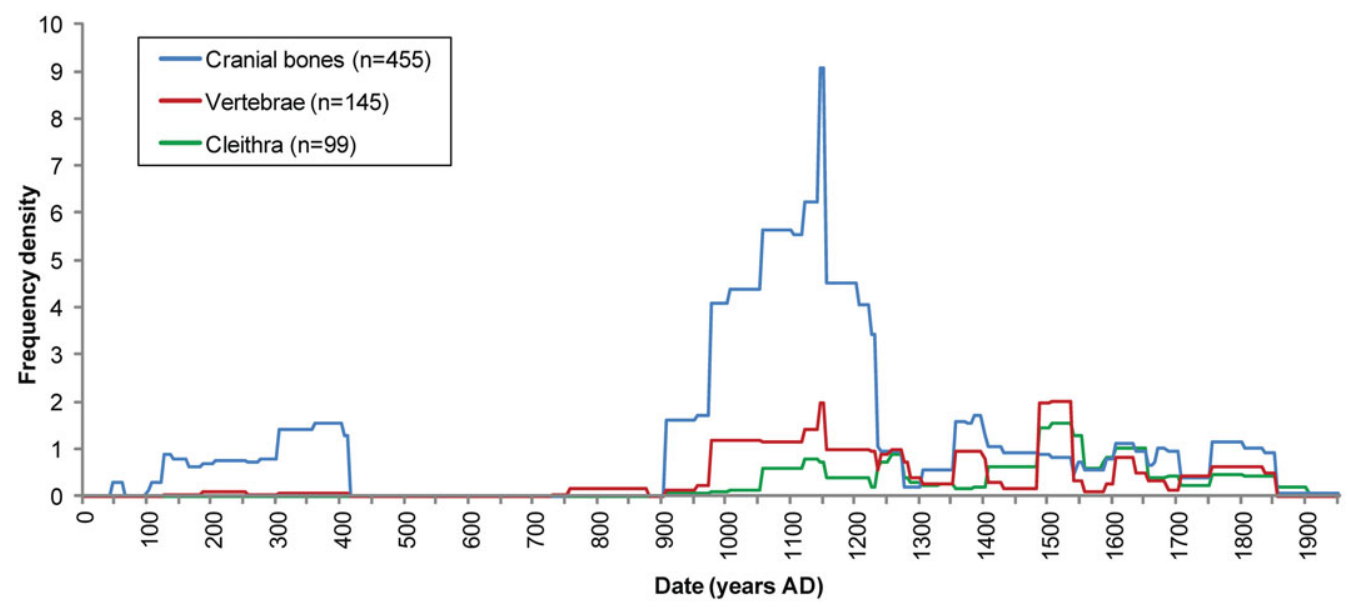

Figure 7. Estimated frequency distributions by anatomical group for London cod specimens recorded in MOLA database.

be informative in broad terms. The relative abundance of cranial and postcranial bones, meanwhile, is independent of sample size at any particular date.

\section{Isotopic data}

The isotopic provenancing data used here are taken from Barrett et al. 2011, with two minor amendments to the dating. Cranial 'control' bones from numerous sites were used to establish regional carbon $\left(\delta^{13} \mathrm{C}\right)$ and nitrogen $\left(\delta^{15} \mathrm{~N}\right)$ isotope signatures for six potential producing regions. 34 postcranial 'target' specimens from London were then assigned to the most likely source region using Discriminant Function Analysis. Since this is a probabilistic method, the predicted sources used here should not be taken as definitive, but as reasonably confident 'best guesses'. Full methodology and results are given in the original paper (Barrett et al. 2011).

(C) Antiquity Publications Ltd. 


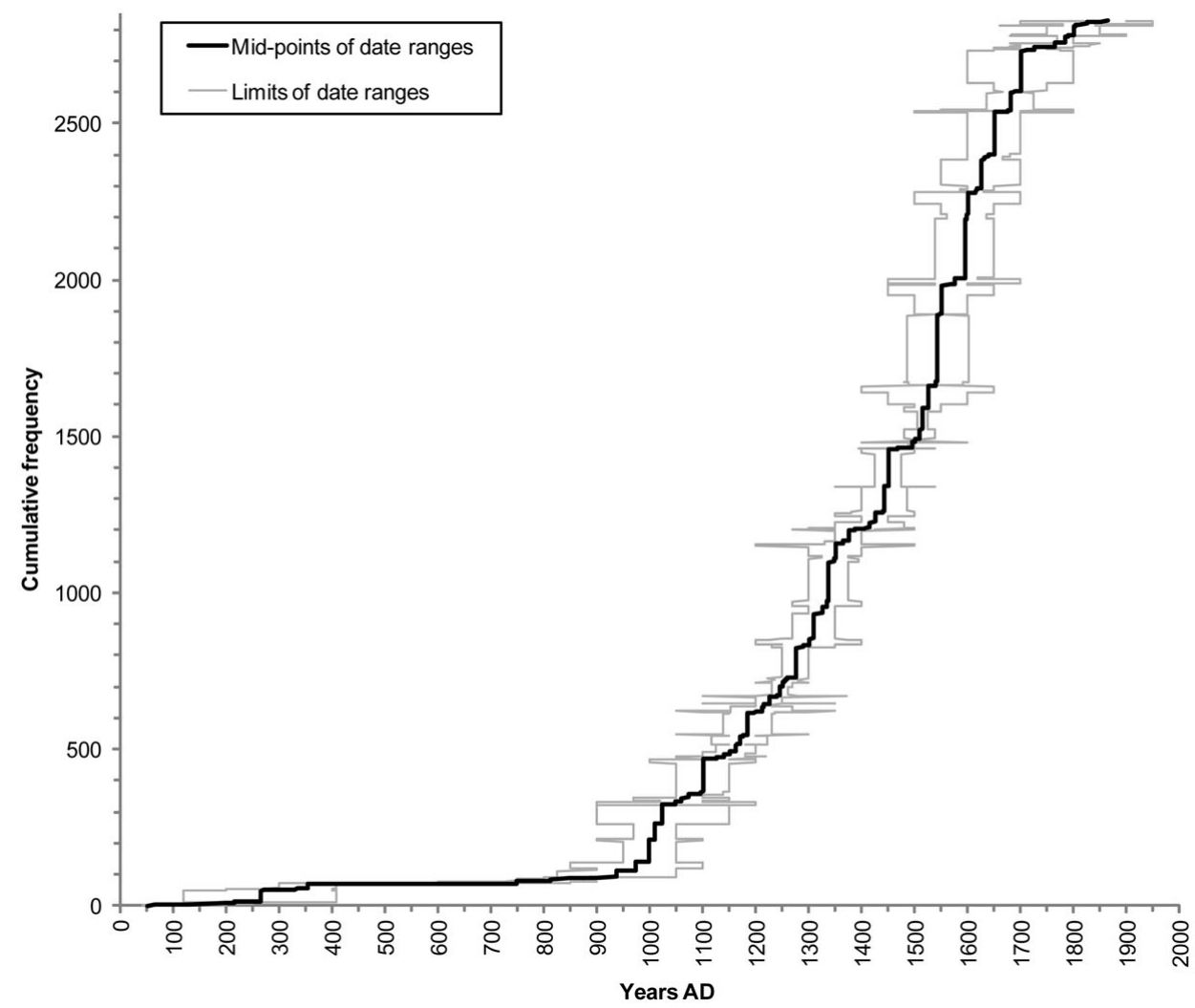

Figure 8. Cumulative frequency curve (black line) for specimens used in study, based on mid-points of date ranges. Grey lines show limits of date range for each specimen.

\section{Results}

Figure 3 shows the estimated frequency distribution for cranial and postcranial cod specimens from London by date. Apart from around 70 Roman-period specimens and a handful from Saxon London, cod only became common within a few decades of AD 1000, matching the national picture (Barrett et al. 2004). Additional increases in frequency are then seen in the thirteenth century and again in the fifteenth and sixteenth centuries, along with shorterterm fluctuations (such as a dip in the late fourteenth century), before a final drop-off after AD 1700. Revealingly, the increase in the 1200s represents a surge in numbers of postcranial elements. The frequency of cranial bones actually falls sharply at exactly the same point, indicating a dramatic shift away from locally caught cod and towards imported fish. From this point onward there is little change in frequency of cranial bones, whereas substantial fluctuations are observed in the frequency of postcranial specimens. A temporary drop in postcranial frequency in the second half of the fourteenth century-with no matching trough for cranial bones - suggests a decline specifically in imports. Conversely, postcranial specimens peak again in the fifteenth and (particularly) sixteenth to seventeenth centuriesimplying increases in imports.

(C) Antiquity Publications Ltd. 
Table 1. Cross-tabulation of anatomical groups and recovery types.

\begin{tabular}{lcccc}
\hline & Cranial bones & Vertebrae & Cleithra & Total \\
\hline 'Sampled' & 287 & 1044 & 57 & $\mathbf{1 3 8 8}$ \\
'Unsampled' & 305 & 936 & 200 & $\mathbf{1 4 4 1}$ \\
Total & $\mathbf{5 9 2}$ & $\mathbf{1 9 8 0}$ & $\mathbf{2 5 7}$ & $\mathbf{2 8 2 9}$ \\
\hline
\end{tabular}

Before accepting these observations at face value we must evaluate potential biases introduced by differential field recovery and laboratory recording methods. Since our metaanalysis considers 95 sites excavated between 1972 and 2008, comprehensive information regarding recovery methodology is not available. The simplest proxy for controlled recovery is whether or not specimens derived from 'environmental samples' (volumes of sediment intended for specialist ecofact analysis and usually wet-sieved), since these were typically attributed an additional sample identification number. For our purposes, bones known to have been recovered by sieving during excavation without having been assigned sample numbers are added to this 'sampled' group, but some sieved material may remain unrecognised.

When the sampled and unsampled bones are plotted through time, chronological divergences in their relative abundance are evident (Figures $4 \& 5$ ), making it essential to consider possible recovery factors when interpreting temporal trends in the anatomical data. Accordingly, Table 1 illustrates the relationship between recovery and anatomy. There is a statistically significant association when cranial elements, vertebrae and cleithra are all considered $\left(\chi^{2}=85.04, \mathrm{df}=2, p=<0.0001\right)$, mostly owing to marked overrepresentation of cleithra in hand-collected deposits. Excluding cleithra, vertebrae are over-represented in the sampled material relative to cranial bones, although the relationship is not statistically significant $\left(\chi^{2}=3.29, \mathrm{df}=1, p=0.0696\right)$. Thus, cranial elements and cleithra are likely to show the strongest signal in the hand-collected material whereas vertebrae are likely to be best represented in the sampled data set.

Both the sampled and unsampled groups corroborate the chronology outlined from the combined data set. In the sampled material (Figure 4) the thirteenth-century watershed is evident from a reversal in relative abundance of cranial elements and vertebrae (cleithra are too few to consider). Skull bones are so rare thereafter that they cease to be a useful indicator of temporal trends, but vertebrae show a sixteenth- to seventeenth-century peak. There is also a hint of a late fourteenth-century decline in imports (vertebrae). In the unsampled material (Figure 5) the thirteenth-century decline in cranial elements is more gradual, but a major shift towards imports at this point is evident as an increase in vertebrae-despite the bias against their recovery-and, slightly later, cleithra. The same applies for fifteenth-and sixteenth-seventeenth-century peaks, with the reverse evident during the temporary decline of the late fourteenth century. The most meaningful difference between the sampled and unsampled data sets is that a smaller absolute number of bones was recovered by sieving prior to the late fifteenth century-which is of limited significance here.

Having considered recovery issues, it remains to address possible biases introduced by differing identification and recording practices. The key question for present purposes is

(C) Antiquity Publications Ltd. 
whether there are any chronology-dependent differences in the degree to which cranial or postcranial bones were identified to the taxonomic level of species. One cautious approach to identifying the vertebrae of cod-family fish, for example, is to assign them to taxonomic family (Gadidae) or to groups of genera that have similar anatomies (e.g. Gadus/Pollachius) (cf. Barrett et al. 1999) rather than to cod itself (Gadus morhua). If the London data were analysed by a wide diversity of specialists it would be difficult to evaluate this potential source of bias. In the event, however, 98 per cent of the primary data were collected by Alison Locker or by the zooarchaeological staff of MOLA following broadly consistent in-house protocols. Figures 6 and 7 compare these two groups.

On comparing the Locker and MOLA data sets it is evident that vertebrae and cranial elements have been treated differently, yet both figures exhibit the thirteenth-century watershed in their own way. In the Locker data there is a surge in postcranial elements whereas in the MOLA data there is a plunge in cranial elements. Both are consistent with a shift in emphasis from local to imported fish, with the MOLA data implying a more conservative approach to the identification of gadid vertebrae, frequently using taxonomic family rather than species. There is more divergence between the groups when it comes to the subsequent trends discussed above. The late fourteenth-century dip and the fifteenthcentury recovery in the abundance of postcranial bones only show in the Locker data set, whereas the sixteenth-century peak in probable imports is evidenced by both. The overall picture is consistent given that the MOLA sample size is very small for the fourteenth to fifteenth centuries when interpretations diverge.

After the Fish Event Horizon around AD 1000 there was a significant introduction of imported cod in the thirteenth century. This most significant watershed was probably followed by a slight reduction in the late fourteenth century before imports increased again in the fifteenth century and (particularly) in the sixteenth to seventeenth centuries.

In theory these 'imports' need not have come from especially distant waters: the anatomical data alone might simply reflect, for example, a shift toward landing and processing more fish in other eastern English ports before shipping them on to the capital. To this end, Figure 9 sets the medieval and early post-medieval portion of the frequency distribution against the results of the isotopic provenancing study. The agreement is striking: prior to the thirteenthcentury shift in relative frequencies, all but one of the sampled specimens-a vertebra from Westminster Abbey dated AD 950-1050-have isotopic values consistent with an origin in the southern North Sea. From AD 1250 onwards the majority of sampled specimens appear to have been imported from distant waters, primarily Arctic Norway and/or the north-east Atlantic (i.e. Iceland and the Scottish islands). Unfortunately the stable isotope data do not permit reliable identification of specimens from waters off Newfoundland (Barrett et al. 2011), but following its European rediscovery in 1497 this must be added to the list of possible sources, and in two sixteenth-century cases is statistically the most likely origin.

\section{Discussion}

The synthesis of London data reinforces the argument that the initial expansion of sea fishing around $\mathrm{AD} 1000$ was driven by demand and/or local technological advances in the southern North Sea area: both the zooarchaeological and isotopic data suggest that

(C) Antiquity Publications Ltd. 

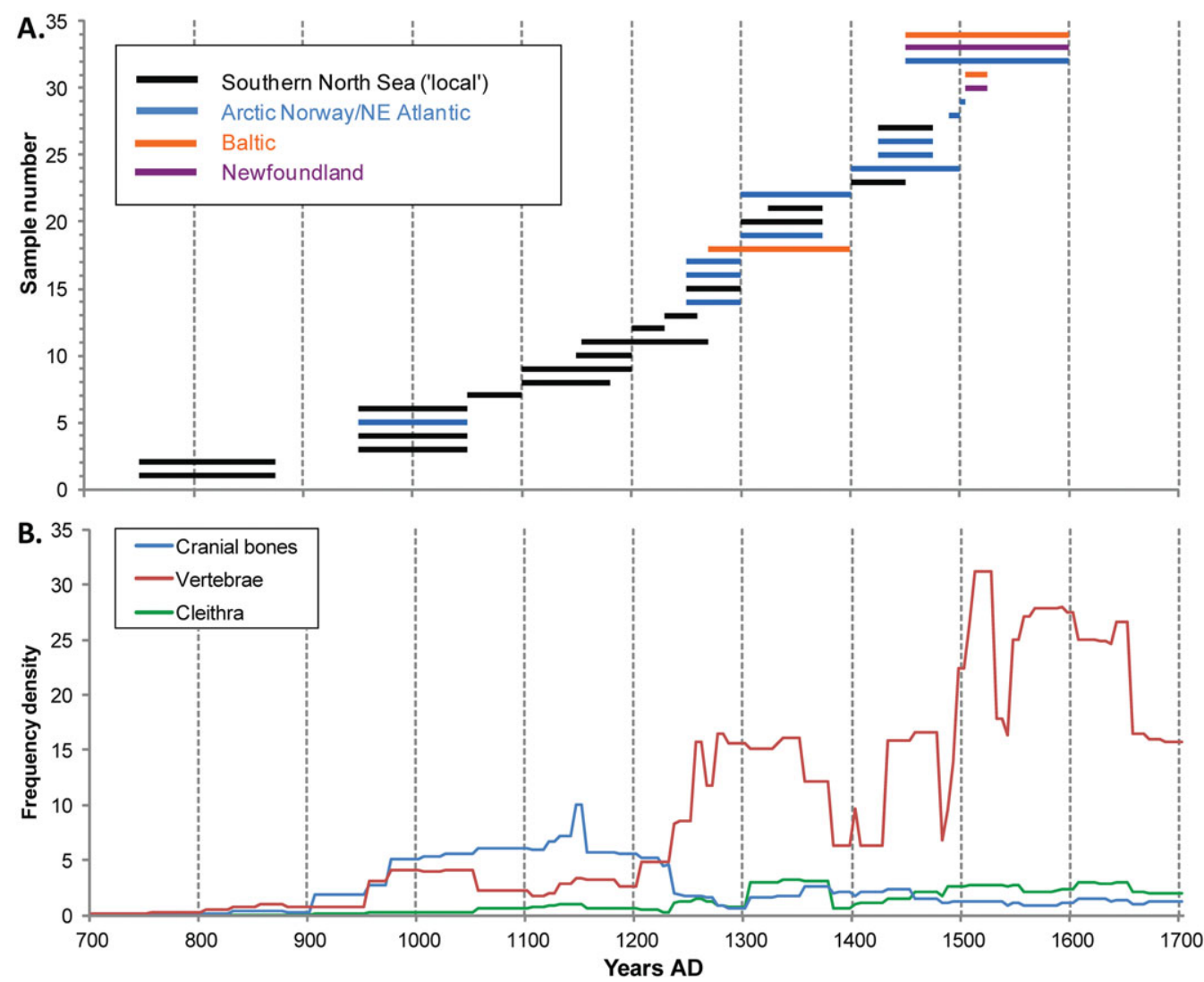

Figure 9. Stable isotopic provenancing results for 34 archaeological cod vertebrae and cleithra from various London sites (A; data from Barrett et al. 2011) set against AD 700-1700 detail of the estimated frequency distributions (B).

eleventh-twelfth-century cod consumed in London were primarily caught in fairly nearby waters and consumed relatively fresh, with imports from northern waters only becoming important later.

A thirteenth-fourteenth-century move towards long-range imports was detected by isotopic research, but the dramatic shift observed in the zooarchaeological record in the thirteenth century is surprising in terms of its suddenness and the apparent decline in locally caught fish. It pre-dates Hanseatic dominance of the Anglo-Norwegian fish trade, which was consolidated in the early decades of the fourteenth century (Lloyd 1991; Nielssen 2009), ruling out one potential explanation. Rising demand from London's growing populationthought to have quadrupled to around 80000 between AD 1100 and 1300 (Campbell et al. 1993: 24) — surely played a part, but the abrupt nature of the switch suggests that supplyside economic factors in producer regions of the north were also relevant. It is unlikely to be a coincidence that English ceramics (e.g. Grimston-type ware) and coins of thirteenthcentury date are abundant finds in Norway (Blackmore \& Vince 1994; Gullbekk 2009: 170-71). Overall, our new chronology is consistent with the hypothesis of punctuated rather than continuous demographic and economic growth in England and Norway prior to the fourteenth century (cf. Langdon \& Masschaele 2006). 
The concurrent decline in cranial bones is absolute (rather than a function of increasing postcranial bones), indicating that local fishing was partly displaced by the increase in imports. It is therefore likely that preserved cod were preferred over 'fresh' ones-perhaps for reasons of longevity and quality. Alternatively, the import trade was a rapid response to decreases in the availability of local catches. These hypotheses cannot be differentiated on present evidence alone. In future research it would thus be valuable to apply similar methods to other major settlements and species-and to examine temporal changes in the length of fish represented by local catches. Work of this kind could illuminate whether the fishermen of south-eastern England simply switched to different markets and/or species, and whether inshore stocks of North Sea cod were already being depleted in the thirteenth century.

Moving forward to the early fourteenth century, the historically attested shift from English and Norwegian to Hanseatic control of the North Sea stockfish trade is invisible in the anatomical evidence. The Great Famine of 1315-17, when English shipments of grain in exchange for Norwegian stockfish were probably disrupted (Hybel 2002: 237), is similarly undetectable, suggesting that its impact on trade was short-lived. The stable isotope evidence also suggests continuity, with imports from the same northern producer regions simply moving via new middlemen. In the case of the isotopic data, however, the growth of German trade networks may be implied by the appearance of possible Baltic cod on the London market.

During the late fourteenth century the abundance of postcranial bones decreased. There was little concurrent drop in cranial bones, suggesting that trade rather than demand had suffered. It may be simplistic to attribute this pattern to the Great Plague alone, despite its demonstrated impact on London (e.g. Sloane 2011). Northern supply chains were probably at least temporarily disrupted following the Black Death, but the city also faced competition for cod from other English ports such as Boston, Bristol and King's Lynn (Kowaleski \& Childs 2000: 34).

Cod imports to London appear to have recovered by the early fifteenth century, concurrent with the expansion of English fishing into Icelandic waters (Gardiner \& Mehler 2007). Moreover, a further increase in the abundance of postcranial bones in the sixteenth and seventeenth centuries coincides with the emergence of an English fishery around Newfoundland and elsewhere along the North American coast (Gray \& Starkey 2000; Pope 2009). The stable isotope data are consistent with this explanation but are currently insufficient to confirm it with any confidence, although ongoing aDNA and sulphur isotope research may improve provenancing power in the future. In any case, the existing isotope results imply that some north-east Atlantic and Baltic cod continued to be imported at this date. Lastly, the final decline in both cranial and postcranial cod bones after AD 1700 is likely to reflect a combination of changing culinary preferences, improved urban waste management and reduced archaeological interest.

To conclude, the thirteenth-century watershed in cod imports to London, and the possibility of a late fourteenth-century disruption, join the 'Fish Event Horizon' as novel archaeological contributions to an interdisciplinary understanding of the economy and historical ecology of medieval Europe. Moreover, we have demonstrated the considerable potential of context-level data as a basis for high-resolution (zoo)archaeological meta-analyses (C) Antiquity Publications Ltd. 
in cities such as London, taking full advantage of the rich but often incompletely published record provided by decades of high-quality urban excavation.

\section{Acknowledgements}

Thanks are due to Museum of London Archaeology staff Alan Pipe, Natasha Powers, David Bowsher and Stephanie Ostrich. Philip Armitage and Hannah Russ provided additional unpublished data. We thank William Hutchinson and Mark Culling for discussions of the data, and Dora Kemp for help with Figure 1. Valuable comments on an earlier draft were provided by Poul Holm and Maryanne Kowaleski, but all shortcomings remain our own. Funding was provided by the Leverhulme Trust and The Fishmongers' Company, while UCL covered the Open Access publication fee.

\section{References}

Adams, J. \& J. Flatman. 2013. High to post-medieval, 1000 to 1650, in J. Ransley \& F. Sturt (ed.) People and the sea: a maritime archaeological research agenda for England: 138-63. York: Council for British Archaeology.

AstiLl, G. 2009. Medieval towns and urbanization, in R. Gilchrist \& A. Reynolds (ed.) Reflections: 50 years of medieval archaeology, 1957-2007: 255-70. Leeds: Maney.

BARRETT, J.H. 1997. Fish trade in Norse Orkney and Caithness: a zooarchaeological approach. Antiquity 71: 616-38.

- (ed.). 2012. Being an islander: production and identity at Quoygrew, Orkney, AD 900-1600. Cambridge: McDonald Institute for Archaeological Research.

BARRETT, J.H., R.A. Nicholson \& R. Cerón-CarrasCo. 1999. Archaeo-ichthyological evidence for long-term socioeconomic trends in northern Scotland: 3500 BC to AD 1500. Journal of Archaeological Science 26: 353-88. http://dx. doi.org/10.1006/jasc.1998.0336

BarretT, J.H., A.M. LocKer \& C.M. Roberts. 2004. 'Dark Age economics' revisited: the English fish bone evidence AD 600-1600. Antiquity 78: 618-36.

Barrett, J.H., D.C. Orton, C. Johnstone, J. Harland, W. Van NeEr, A. Ervynck, C.M. RoberTs, A.M. LOCKER, C. AMUNDSEN, I.B. Enghoff, S. Hamilton-Dyer, D. Heinrich, A.K. Hufthammer, A.K.G. Jones, L. Jonsson, D. MaKowiecki, P. Pope, T.C. O'Connell, T. DE ROO \& M. RICHARDS. 2011. Interpreting the expansion of sea fishing in medieval Europe using stable isotope analysis of archaeological cod bones. Journal of Archaeological Science 38: 1516-24. http://dx.doi.org/10.1016/j.jas.2011.02.017

BlaCKMORE, L. \& A. VincE. 1994. Medieval pottery from south east England found in the Bryggen excavations 1955-68 (Bryggen Papers supplementary series 5). Bergen: Scandinavian University Press.
Campbell, B.M.S., J.A. Galloway, D. Keene \& M. MURPHY. 1993. A medieval capital and its grain supply: agrarian production and distribution in the London region c. 1300 . London: Centre for Metropolitan Research.

CANDOW, J.E. 2009. Migrants and residents: the interplay between European and domestic fisheries in northeast North America, 1502-1854, in D.J. Starkey, J.T. Thór \& I. Heidbrink (ed.) A history of the North Atlantic fisheries, volume 1: from early times to the mid-nineteenth century: 416-52. Bremen: H.M. Hauschild.

Dollinger, P. 1999. The German Hansa. London: Routledge.

Dyer, C. 2002. Making a living in the Middle Ages. London: Yale University Press.

Ervynck, A., W. Van NeEr \& M. Pieters. 2004. How the north was won (and lost again): historical and archaeological data on the exploitation of the North Atlantic by the Flemish fishery, in R.A. Housely \& G.M. Coles (ed.) Atlantic connections and adaptations: economies, environments and subsistence in lands bordering the North Atlantic: 230-39. Oxford: Oxbow.

Gardiner, M. \& N. Mehler. 2007. English and Hanseatic trading and fishing sites in medieval Iceland: report on initial fieldwork. Germania 85: 385-427.

GraY, T. \& D.J. STARKEY. 2000. The distant-water fisheries of south west England in the Early Modern period, in D.J. Starkey, C. Reid \& N. Ashcroft (ed.) England's sea fisheries: the commercial sea fisheries of England and Wales since 1300: 96-104. London: Chatham.

GullbeKk, S.H. 2009. Pengevesenets Fremvekst og Fall $i$ Norge i Middelalderen. København: Museum Tusculanums.

Hoffmann, R.C. 2001. Frontier foods for late medieval consumers: culture, economy, ecology. Environment and History 7: 131-67. http:// dx.doi.org/10.3197/096734001129342432 
Holm, P., D.J. STARKey \& J. Thór. 1996. The North Atlantic fisheries, 1100-1976: national perspectives on a common resource. Esbjerg: North Atlantic Fisheries History Association.

Hufthammer, A.K. Forthcoming. Fish trade in Norway 800-1400: zooarchaeological evidence, in J.H. Barrett \& D.C. Orton (ed.) Cod and consequences: the archaeology and history of medieval sea fishing. Oxford: Oxbow.

Hybel, N. 2002. The grain trade in northern Europe before 1350. The Economic History Review 55: 219-47. http://dx.doi.org/10.1111/1468-0289.00219

KOWALESKI, M. \& W. CHILDS. 2000. The internal and international fish trades of medieval England and Wales, in D.J. Starkey, C. Reid \& N. Ashcroft (ed.) England's sea fisheries: the commercial sea fisheries of England and Wales since 1300: 29-35. London: Chatham.

Langdon, J. \& J. Masschaele. 2006. Commercial activity and population growth in medieval England. Past and Present 190: 35-81. http://dx.doi.org/10.1093/pastj/gtj005

LLOYD, T.H. 1991. England and the German Hanse, 1157-1611. Cambridge: Cambridge University Press. http://dx.doi.org/10.1017/CBO9780511560279

McGHEE, R. 2003. Epilogue: was there continuity from Norse to post-medieval exploration of the New World?, in J.H. Barrett (ed.) Contact, continuity and collapse: the Norse colonization of the North Atlantic: 239-48. Turnhout: Brepols.

NAGAOKA, L. 2005. Differential recovery of Pacific Island fish remains. Journal of Archaeological Science 32: 941-55. http://dx.doi.org/10.1016/j.jas.2004.12.011

NedKVITNE, A. 1994. How important was Hansa trade for the Norwegian economy, in V. Henn \& A. Nedkvitne (ed.) Norwegen und die Hanse: 9-18 Frankfurt: Peter Lang.

Nicholson, R.A. 1998. Bone degradation in a compost heap. Journal of Archaeological Science 25: 393-403. http://dx.doi.org/10.1006/jasc.1997.0208
Nielssen, A.R. 2009. Norwegian fisheries c. 1100-1850, in D.J. Starkey, J.T. Thór \& I. Heidbrink (ed.) A history of the North Atlantic fisheries, volume 1: from early times to the mid-nineteenth century: 83-109. Bremen: H.M. Hauschild.

Perdikaris, S. \& R.H. MCGovern. 2008. Codfish and kings, seals and subsistence: Norse marine resource use in the North Atlantic, in T.C. Rick \& J.M. Erlandson (ed.) Human impacts on ancient marine ecosystems: a global perspective: 187-214. Berkeley: University of California Press.

Pope, P. 2009. Transformation of the maritime cultural landscape of Atlantic Canada by migratory European fishermen, 1500-1800, in L. Sicking \& D. Abreu-Ferreira (ed.) Beyond the catch: fisheries of the North Atlantic, the North Sea and the Baltic, 900-1850: 123-54. Leiden: Brill.

Sloane, B. 2011. The Black Death in London. Stroud: History Press.

Starkey, D.J., J.T. Thór \& I. Heidbrink (ed.). 2009. $A$ history of the North Atlantic fisheries, volume 1: from early times to the mid-nineteenth century. Bremen: H.M. Hauschild.

Stevens, W. \& S.L. CumbaA. 2007. Marine archaeology and zooarchaeology of the 16th-century whaling harbour of Red Bay, in R. Grenier, M.-A. Bernier \& W. Stevens (ed.) The underwater archaeology of Red Bay: Basque shipbuilding and whaling in the $16^{\text {th }}$ century. Volume I: 189-201. Ottawa: Parks Canada.

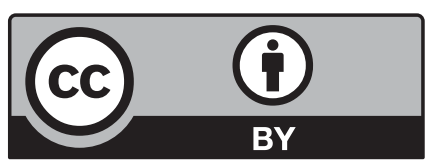

This work is licensed under the Creative Commons Attribution 3.0 Unported License. To view a copy of this license, visit http://creativecommons.org/ licenses/by/3.0/

Received: 13 June 2013; Accepted: 27 August 2013; Revised: 2 September 2013

(C) Antiquity Publications Ltd. 